\title{
Soft wood grafting - A novel and rapid multiplication technique in Coorg mandarin (Citrus reticulate Blanco)
}

\author{
B.M. Muralidhara ${ }^{1}$ and I.N. Doreyappa Gowda ${ }^{2}$ \\ ${ }^{1}$ Scientist (Fruit Science), ${ }^{2}$ Principal Scientist \& Head \\ ICAR-Indian Institute of Horticultural Research \\ Central Horticultural Experimental Station- Chettalli - 571248 \\ ${ }^{1}$ E-mail: muralidhara.bm@gmail.com
}

\begin{abstract}
Coorg mandarin is commercially multiplied by shield or $\mathbf{T}$ budding. The process of shield budding will takes eighteen to twenty months for the production of quality planting material. Hence present experiment was conducted to standardize soft wood grafting in Coorg mandarin to reduce the nursery phase for rapid multiplication of quality planting materials. In this study, two to three months old terminal shoots of Coorg mandarin were grafted on one, two, three and four months old rootstocks of Rangpur lime.The soft wood grafting on three and four months old rootstocks were recorded cent per cent graft success and higher plant survivability $(\mathbf{9 8 \%})$ and minimum was noticed in one month old rootstocks. The plant height $(45.77 \mathrm{~cm})$, plant girth $(0.60 \mathrm{~cm})$, number of leaves per plant $(42.9)$, number of side shoots per plant $(5.65)$, root length $(33.15 \mathrm{~cm})$ and root spread $(8.29 \mathrm{~cm})$ were also found maximum on four months old root stocks followed by three month old rootstocks. Age of rootstocks have significant difference $(P=0.05)$ for plant weight, shoot weight and root weight in both fresh and dry weight basis. The above findings revealed that, four months old rootstocks are more suitable for soft wood grafting in terms of graft success and plant traits. Soft wood grafting can be gainfully exploited for rapid multiplication of good quality planting material by reducing the nursery phase.
\end{abstract}

Key words: Coorg mandarin, Rangpur lime, Soft wood grafting, success rate

\section{INTRODUCTION}

Citrus fruits have a prominent place among popular and extensively grown tropical and subtropical fruits. Among the citrus fruits, mandarins are the most important one grown in India. There are three distinct ecotypes of mandarin (Citrus reticulata Blanco) in India viz., Nagpur mandarins, Coorg mandarins and Khasi mandarins. Coorg mandarin is one of the most important crops grown as component crop in coffee based cropping system in Coorg, Hassan and Chikkamagalur districts of Karnataka and some parts of Kerala and Tamil Nadu. The area under Coorg mandarin is decreasing gradually due to many factors such as greening, Phytophthora, Tristeza virus and lack of availability of quality planting material for establishment of new plantations and replanting. Coorg mandarin is commercially propagated by shield and T-budding wherein rootstock used is $1 \frac{1 / 2}{2}$ to 2 years old (Karunakaran et al., 2014) and takes long time for production of quality planting material. Presently there is huge demand for planting material and it is unable to meet the demand through conventional budding. Hence there is an urgent need for alternate rapid multiplication technique which fastens the planting material production by reducing nursery phase. Micro-budding is a new propagation technique and standardized in Citrus species which could revolutionize the commercial citrus industry by saving grower's time, space and money. Skaria and Zhang (2000) first developed this technique and later this was standardized in Nagpur mandarin, sweet orange and grapefruit (Vijayakumari and Singh, 2003; Alam et al., 2006; Mazhar et al, 2006). This technique was also tried in Coorg mandarin (Karunakaran et al., 2014) but it was not successful commercially due to 
less graft success. Soft wood grafting will help in rapid multiplication and reduces the cost of production as well as early detection of virus and virus-like diseases in plants through the biological indexing (Ochoa et al., 2000; Vijayakumari et al., 2008). Therefore, present study was formulated to observe performance of soft wood grafting in Coorg mandarin on different aged rootstocks of Rangpur lime and which is beneficial for commercial citrus growers and nurserymen to strengthen Coorg mandarin cultivation in Karnataka, Kerala and Tamil Nadu. It will also help to double the production of quality planting material by reducing nursery phase and cost of production.

\section{MATERIAL AND METHODS}

The present study was carried out at the Central Horticultural Experiment Station, Chettalli, Kodagu, Karnataka, India during 2016-17 under poly house condition. The soft wood grafting was carried out in the month of December 2016.

Production of Rootstocks: The fruits of Rangpur lime (Citrus limonia Osb.), were collected from healthy mother plants and seeds were extracted. The fresh seeds weresown inplastic trays at primary nursery. The seedlings were transplanted to polybags containing soil:sand:farm yard manure $(1: 1: 1)$ atsecondary nursery, when they attained 4-5 leaf stage. After transplanting, one, two, three and four month's old rootstocks were used for soft wood grafting.

Selection of scion: Sixty to ninety days old terminal shoots were used as scion material from healthy Coorg mandarin mother plants which are grown under polyhouse condition. Seven to ten days prior to grafting the selected scion shoots were defoliated on mother plants. Scions of 1.0-2.0 mm thickness and $5-10 \mathrm{~cm}$ length were used for grafting.

Technique of soft wood grafting : Rootstocks were headed back at 6 to $15 \mathrm{~cm}$ above the polythene bag and the leaves of rootstock were removed leaving 2-3 leaves on the lower side before grafting. Rootstock was split 1.5 to $2 \mathrm{~cm}$ deep through the centre of the stem with a grafting knife. A wedge-shape cut, slanting from both the sides $(1.5-2 \mathrm{~cm}$ long) was made on the lower side of the scion shoot. The scion stick was inserted into the split of the stock and aligned properly. The union was tied using a 50-gauge polythene strip.
Use of poly tubes: The grafts were covered with 100 micron polytubes immediately after grafting will help in early sprouting and success of grafting. Use of poly tubes will help to retain moisture content in scion and to avoid diffusion of water into graft union at the time of watering in initial stages. Diffusion of water into graft union will lead to failure of grafts at initial period.

Observations recorded: Daily observations were taken for initiation of sprouting and completion of sprouting. The graft success was calculated by using the formula $i . \mathrm{e},\{$ (Number of grafts sprouted/ Total number of plants grafted) x 100\}. After 180 days of grafting all the parameters such as plant survival (\%) $\{$ (Survived plants/ graft success plants) x 100\}, plant height $(\mathrm{cm})$, plant girth $(\mathrm{cm})$, number of leaves per plant, number of side shoots per plant, root length $(\mathrm{cm})$, root spread $(\mathrm{cm})$, plant fresh and dry weight $(\mathrm{g})$, shoot fresh and dry weight $(\mathrm{g})$, root fresh and dry weight $(\mathrm{g})$ were recorded.

Design and Statistical analysis: The experimental design used was completely randomized design.There were four treatments which are replicated four times. Twenty five plants were used for each replication. Data were expressed as means of standard deviation. ANOVA (SPSS version 16.0) and Turkey's post hoc test were used to determine the mean difference of different variables at different age of rootstocks.

\section{RESULTS AND DISCUSSION}

The age of rootstocks showed significant $(P=0.05)$ effect on initiation of sprouting, completion of sprouting, graft success and graft survival (Table 1). Coorg mandarin grafted on four months old rootstocks showed early initiation of sprouting on $11^{\text {th }}$ day and took minimum (12.9) days for completion of sprouting and it was at par with the plants grafted on three months old rootstocks. Delayed sprouting was observed, where Coorg mandarin was grafted on one month old rootstocks in terms of initiation (18.75) and completion of sprouting (21.75). The early sprouting in four months old rootstocks may be due to, rapid callus formation between xylem and cambium tissues in the scion and rootstock union (Hartmann et al., 1997).

Cent per cent graft success was recorded in two, three and four month's old rootstocks whereas 89 per cent was observed in one month old rootstoc. The higher 
Table 1. Influence of age of rootstocks on success of soft wood grafting in Coorg mandarin

\begin{tabular}{|c|c|c|c|c|}
\hline $\begin{array}{c}\text { Age of rootstock } \\
\text { in months }\end{array}$ & $\begin{array}{c}\text { Days taken for } \\
\text { first sprouting }\end{array}$ & $\begin{array}{c}\text { Days taken to } \\
\text { complete sprouting }\end{array}$ & $\begin{array}{c}\text { Graft success } \\
(\%)\end{array}$ & $\begin{array}{c}\text { Graft Survival } \\
(\%)\end{array}$ \\
\hline One & 18.75 & 21.75 & 89 & 86.37 \\
\hline Two & 17.5 & 20.25 & 100 & 91.0 \\
\hline Three & 13 & 15.15 & 100 & 98.0 \\
\hline Four & 11 & 12.9 & 100 & 98.0 \\
\hline CD $(P=0.05)$ & 2.87 & 2.97 & 6.83 & 6.59 \\
\hline CV $(\%)$ & 12.38 & 11.01 & 4.56 & 4.58 \\
\hline
\end{tabular}

percentage of graft success in four months old rootstocks might be due to appropriate age of rootstock with higher sugars and moderate $\mathrm{C}: \mathrm{N}$ ratio (Deshmukh et al., 2017). The decline in graft success in one month rootstocks may be due to physiological condition of rootstock and decreased sap flow or quick cell dehydration, proliferation of callus tissues by both the graft components leading to vascular discontinuity arising from inadequate physiological maturity of rootstock (Wang and Kollmann, 1996).

The similar results were also reported in Coorg mandarin (Karunakaran et al., 2014), Nagpur mandarin (Vijayakumari et al., 2003) and Khasi mandarin (Dubey et al., 2004). Plant survival per cent was higher in Coorg mandarin grafted on three (98\%) and four month's (98\%) old rootstocks where as lowest plant survivability was noticed in one month old rootstocks $(86.37 \%)$. The higher survival on three and four months old rootstocks which may be due to strong stock-scion interaction which is very much necessary for water and essential nutrient flow (Prez-alfocea et al., 2010) and findings are in line with Deshmukh et al (2017) and Patel et al (2010).
After 180 days of grafting plant morphological traits were recorded and mean values were presented in Table. 2. The maximum plant height $(45.77 \mathrm{~cm})$, plant girth $(0.60 \mathrm{~cm})$, number of leaves per plant (42.90), number of side shoots per plant (5.65), root length $(33.15 \mathrm{~cm})$ and root spread $(8.29 \mathrm{~cm})$ was recorded in Coorg mandarin grafted on four months old rootstocks and followed by three months old rootstocks. The low values were observed in one month rootstocks for all the traits viz., plant height $(28.65 \mathrm{~cm})$, plant girth $(0.38 \mathrm{~cm})$, number of leaves per plant (22.55), number of side shoots per plant (2.88), root length $(22.62 \mathrm{~cm})$ and root spread (3.74 $\mathrm{cm})$. The better morphological characters in the plants grafted on four month old rootstocks is due to suitable maturity of rootstock as well as rapid and better union of stock and scion (Skene et al., 1983) is influencing the better absorption of nutrients by more number of leaves and higher number of side shoots. Desmukh et al (2017) also found better morphological traits when they grafted Kashi mandarin on six months old rootstocks of rough lemon and similar results were reported for plant height and girth by Patel et al

Table 2. Influence of age of rootstocks on morphological characters of grafted plants

\begin{tabular}{|c|c|c|c|c|c|c|}
\hline $\begin{array}{c}\text { Age of } \\
\text { rootstock in } \\
\text { months }\end{array}$ & $\begin{array}{c}\text { Plant } \\
\text { height } \\
(\mathrm{cm})\end{array}$ & $\begin{array}{c}\text { Plant } \\
\text { girth } \\
(\mathrm{cm})\end{array}$ & $\begin{array}{c}\text { Number of } \\
\text { leaves } \\
\text { per plant }\end{array}$ & $\begin{array}{c}\text { Number of } \\
\text { side shoots } \\
\text { per plant }\end{array}$ & $\begin{array}{c}\text { Root } \\
\text { length } \\
(\mathrm{cm})\end{array}$ & $\begin{array}{c}\text { Root } \\
\text { Spread } \\
(\mathrm{cm})\end{array}$ \\
\hline One & 28.65 & 0.38 & 22.55 & 2.88 & 22.62 & 3.74 \\
\hline Two & 32.52 & 0.45 & 28.48 & 3.40 & 24.75 & 4.96 \\
\hline Three & 38.47 & 0.47 & 36.45 & 4.33 & 24.27 & 5.90 \\
\hline Four & 45.77 & 0.60 & 42.90 & 5.65 & 33.15 & 8.29 \\
\hline CD $(P=0.05)$ & 1.86 & 0.045 & 3.65 & 0.74 & 1.82 & 0.91 \\
\hline CV $(\%)$ & 3.32 & 5.51 & 7.27 & 11.81 & 4.31 & 10.33 \\
\hline
\end{tabular}


(2010). The four months' rootstocks recorded maximum root length and root spread due to the synthesis of required amount of secondary metabolites like phenols and alkaloid compounds which are most important for protection of rootstock by less root infestation by soil borne pathogens (El-motty et al., 2010; Qiang et al., 2010). Deshmukh et al (2017) also observed maximum root length $(385.36 \mathrm{~cm})$ on six months old rootstocks of rough lemon.

The results also revealed that, the differences among plant traits viz., plant fresh and dry weight, shoot fresh and dry weight, root fresh and dry weight were significantly $(P=0.05)$ influenced by age of rootstocks (Table 3). The higher plant fresh weight $(23.15 \mathrm{~g})$, plant dry weight $(8.34 \mathrm{~g})$, fresh shoot weight (15.07 $\mathrm{g})$, dry weight $(5.16 \mathrm{~g})$, root fresh weight $(8.09 \mathrm{~g})$ and dry weight (3.18 g) were recorded in four months old rootstocks followed by three months old rootstocks. The one month old rootstocks showed minimum values for plant fresh weight $(9.31 \mathrm{~g})$, plant dry weight (2.82 g), fresh shoot weight (5.76 g), dry weight (1.77 g), root fresh weight $(3.56 \mathrm{~g})$ and dry weight $(1.05 \mathrm{~g})$. The Coorg mandarin grafted on four months old rootstocks have better biomass compared to grafts on one month old rootstock and this is mainly due to the higher age of plants which will help for better growth of scion and root system. The higher dry weight of four month rootstocks indicates the presence of higher vigour.

In Conclusion, soft wood grafting of two to three months old terminal shoots of Coorg mandarin on four months old rootstocks of Rangpur lime have more graft success and better graft growth. Exploitation of soft wood grafting in Coorg mandarin will be very much useful in doubling the production of quality planting material by shortening the nursery phase and reducing the cost of planting material production. Further studies are required to evaluate the performance of grafted plants in field condition for growth and yield.

Table 3. Influence of age of rootstocks on biomass accumulation of soft wood grafted plants

\begin{tabular}{|c|c|c|c|c|c|c|}
\hline \multirow{2}{*}{$\begin{array}{c}\text { Age of } \\
\text { rootstock in } \\
\text { months }\end{array}$} & \multicolumn{2}{|c|}{ Plant weight } & \multicolumn{2}{c|}{ Shoot weight } & \multicolumn{2}{c|}{ Root weight } \\
\cline { 2 - 7 } & Fresh $(\mathrm{g})$ & Dry $(\mathrm{g})$ & Fresh $(\mathrm{g})$ & Dry $(\mathrm{g})$ & Fresh $(\mathrm{g})$ & Dry $(\mathrm{g})$ \\
\hline One & 9.31 & 2.82 & 5.76 & 1.77 & 3.56 & 1.05 \\
\hline Two & 13.54 & 4.32 & 8.78 & 2.71 & 4.77 & 1.61 \\
\hline Three & 17.31 & 5.58 & 11.34 & 3.69 & 5.98 & 1.89 \\
\hline Four & 23.15 & 8.34 & 15.07 & 5.16 & 8.09 & 3.18 \\
\hline $\mathrm{CD}(P=0.05)$ & 1.61 & 0.91 & 1.05 & 0.81 & 0.71 & 0.16 \\
\hline $\mathrm{CV}(\%)$ & 6.61 & 11.32 & 6.71 & 15.8 & 8.34 & 5.59 \\
\hline
\end{tabular}

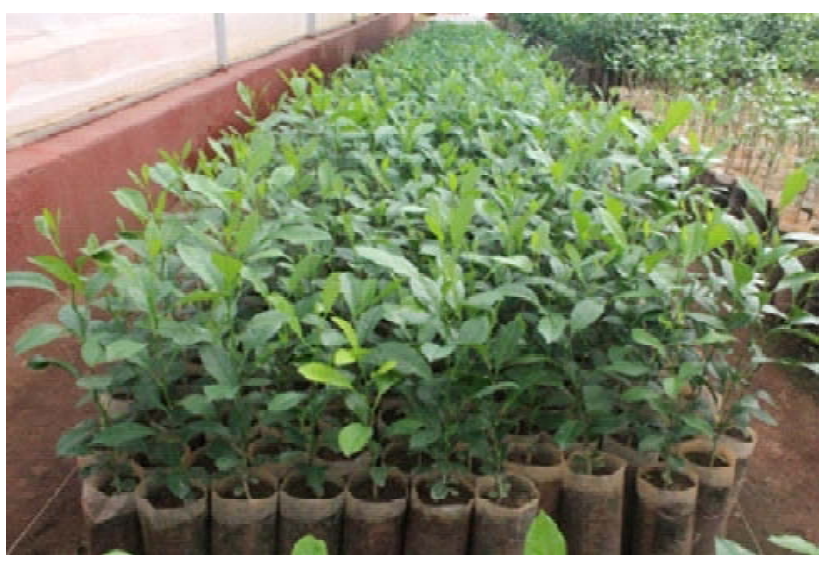

Fig. 1. Four months old rootstocks of Rangpur lime

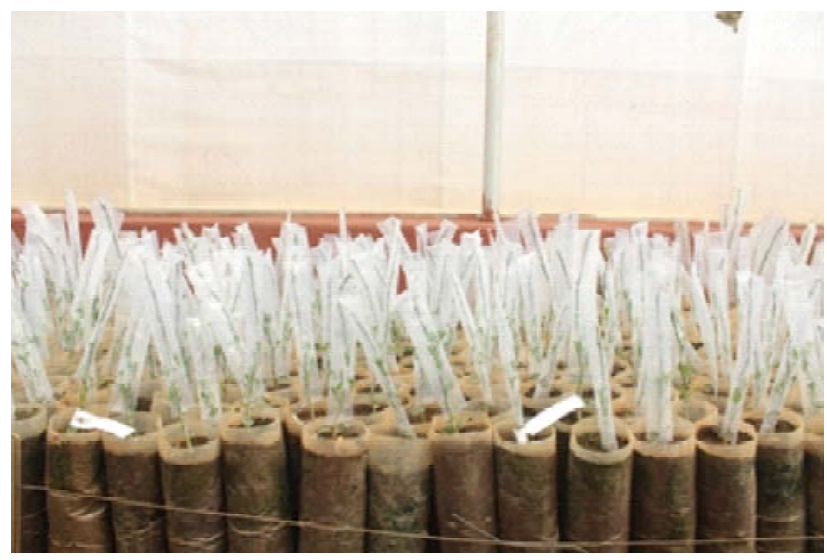

Fig. 2. Grafts covered with poly tubes 


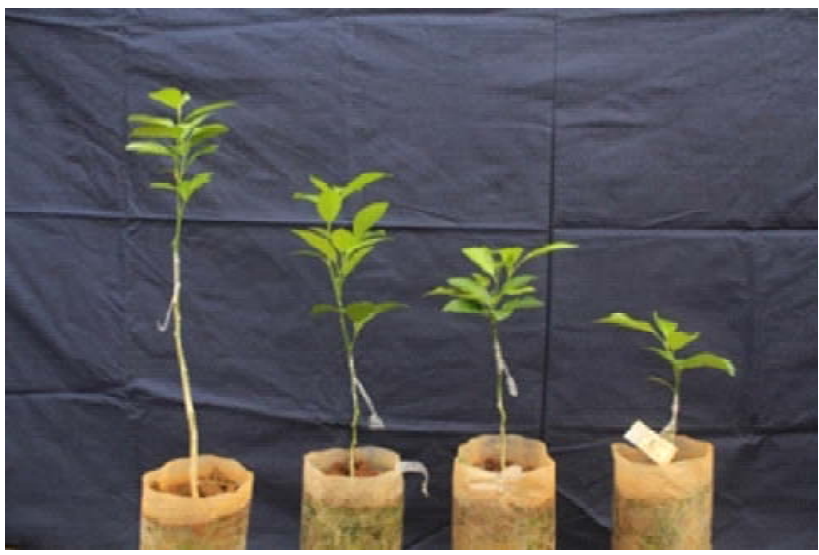

Fig. 3. Successful grafts of Coorg mandarin on different aged rootstocks of Rangpur lime

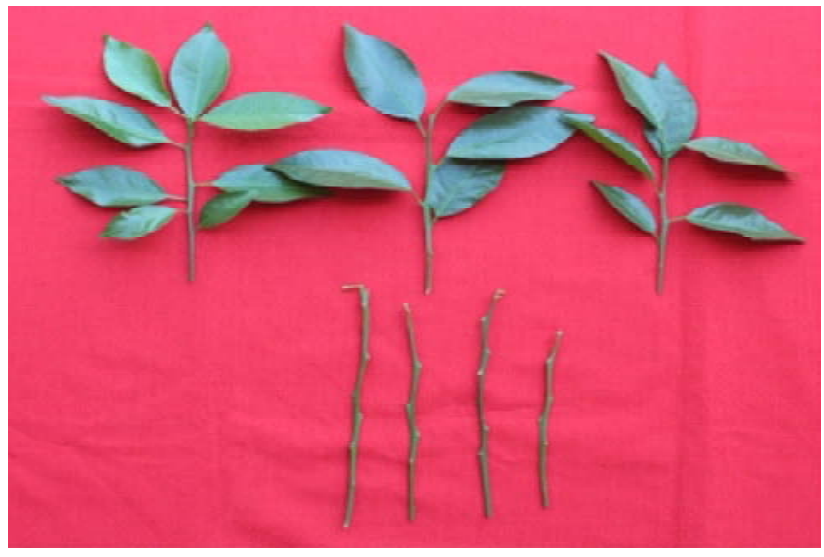

Fig.5. Scion suitable for successful grafting

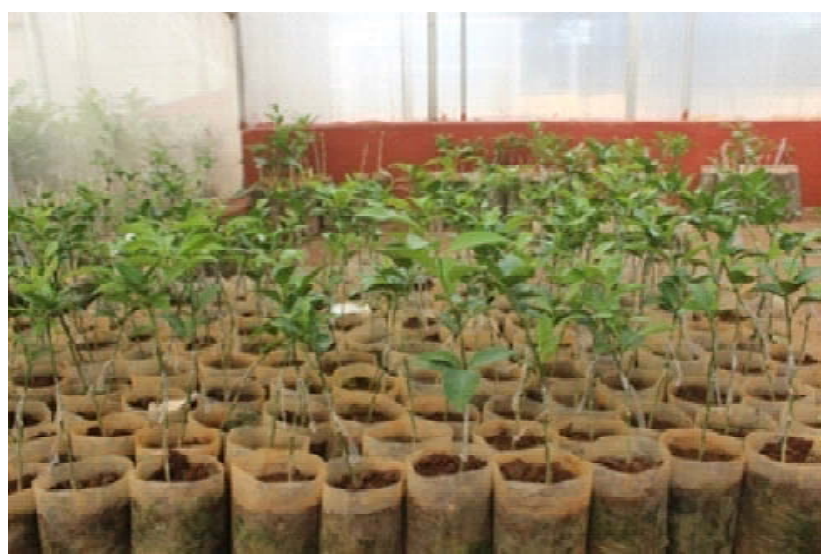

Fig. 4. General view of three month's old grafted plants

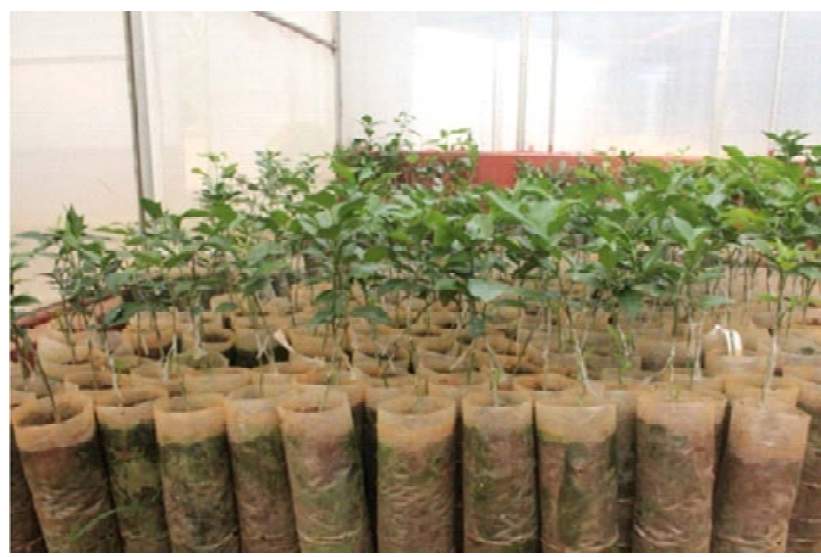

Fig.6. General view of successful grafted plants

\section{ACKNOWLEDGEMENT}

The authors gratefully acknowledge Director ICAR-Indian Institute of Horticulture Research, Bengaluru for guidance and encouragement during the study. We also thank grafter Mr. Madhesh for successful grafting work.

\section{REFERENCES}

Alam, N., Naveed, F., Khan M.M., Abbas, M. and Ahmad, S. 2006. Early age propagation of three commercial Citrus species through microbudding technique. Pak. J. Agri. Sci., 43: $42-44$.

Deshmukh, N.A., Patel, R.K., Krishnappa, R., Verma, B.C., Rymbai, H., Assumi, S.R., Lyngdoh, P., Jha, A.K. and Malhotra, S.K. 2017. Influence of rootstock age and propogation methods on scion physiology and root morphology of Khasi mandarin (Citrus reticulata). Ind. J. Agri. Sci., 87: 203-209
Dubey, A.K., Mishra, M. and Yadav, D.S. 2004. Softwood grafting in Khasi mandarin (Citrus reticulata Blanco). Ind. J. Hort. Sci.,61: 263-4.

EI-Motty, E.Z.A., Metwally, S.E., Abou, Y.R. and Farahat, S.A. 2010. Studies on growth, nutritional and microbiological status of citrus seedlings infested with root-rot disease. Nat. Sci.,8: 112-21

Hartmann, H.T., Kester, D.E., Davies, F.T. and Geneve, R.L. 1997. Plant Propagation: 
Principal and Practices, 8th Edn, pp 770. Prentice Hall of India Pvt Ltd, New Delhi.

Kadam, J.H., Karale, A.R., Garad B.V. and Desai, U.T. 2007. Micro-grafting in wood apple. In: Recent Trends in Horticultural Biotechnology, RaghunathKeshvachandran (Eds.), New India Publishing Agency, New Delhi, pp. 371-73

Karunakaran, G. Ravishankar, H., Sakthivel, T and Samuel, D.K. 2014. Optimization of microbudding technique in Coorg mandarin (Citrus reticulata Blanco). Ind. J. Hort.,71: 311-314

Mazhar, A., Khan, M.M., Mughal, S.M., Jaskani, M.J. and Haider, A. 2006. Propagation of CTV free sweet orange [Citrus sinensisOsb.] plants through microbudding technique. Pak. J. Bot.,38: 583-87

Ochoa, P.M., Dekkers, M.G.H., Skaria, M. and Lee, R.F. 2000. Use of microbudding to expedite production of experimental citrus hosts for use for biological indexing of citrus pathogens. In: ISC Congress, Orlando, Florida, pp., 129

Patel, R.K., Babu, K.D. and Akath Singh 2010. Soft wood grafting in mandarin (Citrus reticulata Blanco): A novel vegetative propagation technique. Int. J. F. Sci., 10:54-64

Perez-alfocea, F., Albacete, A., Ghanem, M.E. and Dodd, I.A. 2010. Hormonal regulation of source and sink relations to maintain crop productivity under salinity: a case study of root to shoot signaling in tomato. Functional $\mathrm{Pl}$. Bio.,37:592-603
Qiang, S.W., Ying, N.Z. and Xin, H.H. 2010. Contributions of arbuscularmycorrhizal fungi to growth, photosynthesis, root morphology and ionic balance of citrus seedlings under salt stress. Acta Physiol. Plant.,32:297-304

Skaria, M. and Zhang, T. 2000. Field performance of micro-budded citrus trees in Texas. In: ISC Congress, Orlando, Florida, pp. 130

Skene, D.S., Shepherd, H.R. and Howard, B.H. 1983. Characteristic anatomy of union formation in budded fruit and ornamental tree. J. Hort. Sci.,58:295-299

Vijayakumari, N. and Singh, S. 2003. Standardization of microbudding technique in citrus. Ind. J. Hort. Sci.,60: 127-30

Vijayakumari, N., Singh, S. and Thote, S.G. 2008. Application of micro-budding: A faster propagation technique in citrus. J. Soils and Crops, 18: 89-91

Vijayakumari, N., Singh, S., Ghosh, D.K., Das, A.K. and Dhurjati, T. 2001. Performance of microbudding under different greenhouse structures in Citrus reticulata cv. Nagpur mandarin. South Ind. Hort., 49: 335-37

Wang, Y. and Kollmann, R. 1996. Vascular differentiation in the graft union of in vitro grafts with different compatibility. J. Plant Physiol., 147: 521-33

(MS Received 26 September 2017, Revised 16 May 2018, Accepted 22 June 2019) 